\title{
Book Reviews: Robert Guest (2004) “The Shackled Continent: Power, Corruption, and African Lives"
}

\author{
Tadele Zemede Wubayehu \\ Correspondence: Tadele Zemede Wubayehu, Department of Governance and Development Studies, College of \\ Social Science, Wollega University, Nekemte, Ethiopia.
}

Received: August 21, 2020 Accepted: September 8, 2020 Online Published: September 10, 2020

doi:10.11114/bms.v6i3.5009ＵRL: https://doi.org/10.11114/bms.v6i3.5009

\begin{abstract}
Over the past two decades, extreme poverty has been decreasing in all regions of the world except for sub-Saharan Africa. This attracted the attention of many scholars and policymakers from Africa and other continents of the world to study and understand the reason why Africa has remained so poor. As a result, many scholars have advanced many reasons for poverty and underdevelopment on the continent. However, no consensus is reached among scholars for poverty and underdevelopment of Africa. 'The shackled continent' is one of the books that has attempted to explain the reasons why Africa has remained so poor. The main of this paper was to critically review the book. The shackled continent has critically analyzed and identified many hobbles that have affected the development process in Africa. In this regard, the author assumption is that Africa has remained so poor as a result of several factors which includes failures of leadership, tribal politics, bad governance, impacts of AIDs, resource curse, lack of transparent property rights, ethnic strife, corruption, frequent military coups, and development assistance failures. Guest admits that these reasons to some extent contribute to the Africans' development challenges. However, arguably failures of leadership are the main reason for underdevelopment in Africa. The author argues that global capitalism is merely a solution to Africa's problems. This book has many strengths as well as weaknesses.
\end{abstract}

Keywords: AIDs, bad governance, corruption, leadership, property rights, and resource curse.

\section{Introduction}

"The shackled continent" is a book about why Africa is poor is structured into nine chapters. The author, Guest was a journalist and the editor of the book, Smith was an Economist while writing the book. Over the past two decades, extreme poverty has been decreasing in all regions of the world except for sub-Saharan Africa (SSAs). The author main assumption is that Africa is in a bad way and his book seeks to point out the reasons why Africa countries remained so poor. The 'shackled continent' has attempted to critically analyze the encumbrances that continue to thwart Africa's development. The narrative flows smoothly combining successfully journalistic and economist perspective. Through this book, the author takes us to the roots of problems why Africa remained so poor. In this regard, the author has analyzed and identified many reasons for poverty and underdevelopment on the continent. Among these factors, the author's main assumption is that Africa is poor primarily because it is badly governed or mainly blames African leaders for the underdevelopment of Africa. I found this book is a thought-provoking book about the life of African peoples and African governments. The Shackled Continent and its ideology also came under criticism in many ways. But if you set those complaints aside, this book is compelling. Thus, the shackled continent is an excellent resource for African leaders, policymakers, development practitioners, international donors, and researchers in their attempts to address the challenges that held Africa back, as well as in their search to help design a new commencement for African countries.

\section{Summary of the Book}

This book is organized into nine chapters. In this section, I have summarized the main points that the author raised in whole chapters of the book. It begins with the 'vampire state' and also touched on salient factors like geography, history, slave trade, colonialism, reliance on mineral resources, HIV/AIDS, property rights, ethnic-based politics/tribalism, foreign aids, and free trade. Throughout the book, the author presented how these factors underdeveloped Africa. Unlike, many scholars from Africa like (Mazrui, 1986) who claimed that everything that went wrong in Africa was the fault of Western colonialism and imperialism. Mazrui also noted that the colonial masters damaged Africa's indigenous technological development in several ways by collapsing Africa's infrastructures. However, Guest claimed that bad 
leadership as the main factor responsible for the African crisis or poverty; not colonialism, and its legacy as (Mazrui, 1986) other scholars in Africa claimed for the underdevelopment of Africa. The Guest assumption in this regard is that the colonial masters not only left deep scars on the continent. They also left behind some important things like clinics, roads, and laws. For him, colonialism is not an issue that held Africa back. Guest also noted that if colonialism is what held Africa back, independence would be expected to bring development in Africa. However, much of Africa has stagnated within the past four decades, or after they got their independence. To substantiate his argument on this issue, Guest took South Korea as an example, which went from underdeveloped, to a developed country within a few decades, while most of Africa continued to suffer in poverty. Thus, Guest as an alternative proposes that Africa has corrupt, incompetent, and inefficient leaders not ready to help their people or capable enough to transform the continent. In this regard, Guest argued that since independence "Africa's governments have failed their people this is an attractive good summary of what holds Africa back" (p. 18).

In summary, the whole chapters of the book presented the true conditions/realities of the African countries and factors responsible for the underdevelopment of Africa. In this respect, Guest stated that African people's live under predatory state or what he called, 'vampire states' like, such as Zimbabwe, Rwanda, Nigeria, and incompetent governments; most of the African countries were at a border war/civil war; Africa is endowed with many precious natural resources like gold, diamond, cobalt, gas oil, etc. But the natural resource in Africa has proven more a curse than a blessing. This is because natural resources were not properly managed, income gained from natural resources was used largely by officials in power to meet their needs, and to purchase a gun to maintain their regime. A little amount of income gained from natural resources goes into investment in most African states. Thus, the natural resources in Africa remained a source of conflict and poverty. The author also noted that the absence or the lack of transparent property rights in many African states also discourages investment; AIDS has shortened the life expectancy of Africans, especially the young group or the working force because they did not use self-protection. This also posed burdensome on development in Africa in several ways. The political party in Africa organizes itself based on tribe not based on ideas or ideologies. This also engulfed the democratization processes and democratic responsibilities in Africa. Besides, the author argued that foreign aids given to Africa in billions of dollars go more into the nonproductive sector than the productive sector and it has had a little noticeable effect on the poor; investment is impossible in Africa, and the whole government incline to nepotism and incompetence. Finally, Guest argued that rambling corruption has created a group of elites on the continent who used foreign aid to pay for luxury houses and cars even though their populations starve. According to Guest, all these reasons are what allow poverty to persist in Africa and hampered development process in the region. Looking at the above-mentioned negative pictures of the continent may make someone easily feel as though Africa is beyond repair. However, Guest has not given up on Africa; any country can make the transition from poverty to comfort or development" (p. 28). Finally, the author forwarded many ways that he deemed necessary on how Africa could prosper. In this regard, Guest argued that to properly develop African economies, the past needs to be left behind and citizens must continue to progress. In general, what the author pointed out as a reason for why Africa remained so poor is fascinating and inspiring. But, most of what the author proposed as a solution for Africa to grow faces comes under serious criticisms.

\section{Analysis}

In this section, I have analyzed strengths and critiques of the book by putting the views, or arguments of the author into broad theoretical perspectives, and other scholars view the main question his book seeks to answer. Furthermore, the book was evaluated on the sufficiency of collected data's to answer the main inquiry of the book, the way issues are framed, and arguments are made to answer the main question that the book seeks to answer.

\subsection{Strengths}

The contrast with other existing books/ articles in the genre ( Mazrui, 1986; Ayittey, ND; Mills., 2010 and Julius, 2017) what makes the narrative in Guest's book unique and original is that first-hand accounts from a broad section of countries are used. Furthermore, the shackled continent explored many factors that hampered the development process in Africa from broader perspectives than others. In other words, all factors what the author claimed for the underdevelopment of African countries were studied and documented to a great extent before this book was written. But they haven't analyzed those reasons for the underdevelopment of Africa from broader perspectives or dimensions as Guest. Thus, the shackled continent is unique from the previously existing work in this regard in many ways. First, many scholars claimed colonialism and imperialism as the main reason for the underdevelopment of Africa. But Guest mainly makes African leaders responsible for the underdevelopment of Africa and briefly narrated how African governments underdeveloped Africa. In this regard, Guest briefly concluded that, since independence, Africa's governments have failed their people. Guest also argued that if colonialism was what held Africa back, it was possible to expect that end of it would bring equality, justice, freedom, better social service, social progress, rapid economic growth, and development. However, the end of colonialism in African has not brought the desired outcomes. Instead, 
Guest identified many challenges that African people continued to face post-independence which include bad governance, abuse of power, ethnic conflict, corruption, improper utilization of natural resources and foreign aid, frequent military coup, and bad leadership. Thus, the reasons he provided to substantiate his arguments in this regard are fascinating and convincing.

The author also identified few African countries like South Africa, Angola, Botswana, and Tanzania as the best model for other African countries to follow their footsteps to achieve their development. In this respect, the author identified factors for development in these countries which includes the kind of economic systems or policies they used, governance system they adopted, the way they managed and utilized their natural resources properly, the way they handled ethnic issues, and the way they spent foreign aids for developmental purpose. Thus, this could also be a good lesson for other African countries to follow their paths to come out of poverty traps and achieve sustainable development goals.

The third strength of the book is the author knowingly draws a negative picture of the continent and does an exciting job. Some readers may feel bitter about such a pessimistic narrative about the destructiveness of war, absence of property rights, corruption, bad leadership, poverty, disease, unfulfilled promises, improper utilization of foreign aids and natural resources, absence of a conducive environment for investment, bad governance, ethnic strife, frequent military coups, patrimonial rule, and underdevelopment. Nevertheless, open-minded and visionary Africans would find that this book would give profound insights on how to curb these challenges. Thus, the shackled continent, in its ruthless openness, would give many insights to any concerned bodies in their attempt to address these challenges that held Africa back. Specifically, it could also give many insights to any concerned bodies, in their attempt to design, implement, and monitor policies, programs, and strategies that could contribute to the true renaissance for Africa.

\subsection{Critiques}

To be sure, there are some weaknesses in the book. For the sake of convenience, I summarized my critique on four key issues.

i. Both primary and secondary data are used in the book to identify the reason why Africa has remained so poor. But, the evidence collected and used in this regard are mainly taken from a few individuals and a few particular areas of particular African states. However, the author used these limited data collected from a few areas or sates of Africa and generalized the findings to the whole African states. In this regard, the author's assumption is wrong in many ways. First, he is wrong because he treated all African countries as homogeneous or a single state. Second, the lack of sufficient reliability on facts that relegates the book more in the realm of fiction. Third, the fact that the author relies more on generalizations and makes a cardinal proposal for African renaissance focused on the responsibility of leadership to overcome the poverty trap and continue the development of African states toward economic development.

ii. The second critics of this book come on what the author claims that "Africans are underdeveloped mostly by their governments." This is true in some instances, but Africa is not only underdeveloped by African governments as Guests claimed but also by developed countries. In this way, the author fails to recognize or purposely hide the facts of how developed countries systematically underdeveloped Africa even after they got their independence. The Guest's arguments in this regard also go contrary to the views of 'Dependency theory' of development, arguing that 'those developing countries are systematically underdeveloped by developed countries." Instead, his argument favor's view of the Modernization theory of development which advocates that developing countries like Africa should follow the path or ways of developed countries to achieve their development. Furthermore, what the author proposed as a way to overcome the challenges facing Africa was a kind of imposing western ideology on Africans which is not designed based on the realities existing in the particular African States. Hence, the author's assumption seems that 'one size fits all' or assumed that policies or strategies which were effective in developed countries would also work in African states irrespective of differences they have. But, in the present world, such a view may not work, because polices which are effective in one, may not work in other states. This is because most of the problems and challenges that countries are facing may vary from country to country and created in different contexts and demands different programs, policies, and interventions to address it. But, Guest proposed the same solutions for all states without taking into account the disparities that each state has in their local contexts. This may happen either Guest purposely attempted to impose or advocates the western ideologies as a best which would be effective in solving all problems that all states in the world are facing irrespective of existing cultural differences (local contexts) among them. Or, he failed to consider the fact that problems existing in a particular state are created in a particular context which may vary from problems existing in other states demanding different kinds of policies or interventions based on the realities existing there.

iii. Guest also insists on colonialism is not an issue in Africa. He took South Korea as an example, which went from an underdeveloped country to a developed county in about fifty years, while most of Africa continued to languish in the dumps. Thus, when we make any comparison between different groups we should have to rely on the same 
standards or criteria to measure it, make a generalization or infer insights from it. For instance, in this case, it is imperative to consider some issues like the intentions of colonial masters, the number of foreign aids they received, and the way they utilized post-independence, their geopolitical significance for developed countries, nature of institutions created by colonial masters, effects of colonial legacy, nature of society living in that particular state prior, during or postcolonialism, etc. it is obvious that such factors could create the difference between states in their development processes either by hampering or supporting. However, Guest was not recognized and considered how these factors created a difference between African states and South Korea. Even between African states. For instance, many works of literature in this regard to arguing that the amount of foreign aids goes form the USA to South Korea between 19601990 s ten times higher than the total amount of foreign aids goes to the whole African countries. This might be due to the geopolitical importance of South Korea for the USA. Thus, it obvious such realities could make a difference between states in their development process either by hampering or promoting it. But the Guest has not considered and analyzed such facts and simply generalized that South Korea developed and African countries continued to persist in poverty. Furthermore, the realities on the ground in most of Africa show that colonial legacy and colonial boundaries arbitrary drawn by colonial masters continue to mess the continent but Guest did not mention this as an issue.

iv. Finally, most of the factors the author claimed as the reasons for why Africa has remained so poor are fascinating. But, most of what the author proposed as a solution to fix the problems African are facing may not be a true path for Africans. For instance, he argued that most foreign aids go into the private pockets of government officials in power or those in power. And it is on this premise that Guest argues that the best way the West can help Africans is to open up its borders. His proposals for solving these problems, basic free-market sorts of solutions, are mostly not reasonable. Because free trade is just a thinly veiled program for convincing poor countries like Africa to liberalize their markets so heavily subsidized western companies can flood those markets with underpriced products.

\section{Conclusion}

The shackled continent is a very thought-provoking book about African peoples and African governments. The book pointed out many reasons why Africa has remained so poor. In this regard, the author main assumption is that Africa remained poor primarily because it is badly governed. African governments who largely substituted colonial masters have struggled to keep order rather than creating atmospheres that are conducive for economic development, for investment, and democratization. In general, factors that the author identified as reasons for poverty and crisis in Africa could contribute to the true renaissance of Africa. But some of what the author proposed as a solution seems imposing of western ideologies, which are not created in line with the realities existing in Africa or African cultures. Besides, it may favor at most western countries more than Africa.

\section{Acknowledgments}

First and foremost, I would like to thank the almighty God who made this article to be successful. I would also like to express my profound gratitude to the editor and reviewers of this article, for their tremendous insight and scholarly support in the course of this study. Their constructive feedback and suggestions added great value to this work. Their unreserved support had a significant impact on the present form of this Article.

\section{References}

Ayittey, G. B. N. (nd). Why Africa Is Poor. Available at http://freeafrica.org/wp-content/uploads/2018/04/WHYAFRICA-IS-POOR.pdf

Guest, R. (2004). The shackled continent: power, corruption, and African lives. Washington, D.C: By Smithsonian Books in association with Macmillan, an imprint of Pan Macmillan Ltd.

Julius, K. O. (2017). Why Most African Countries Are Poor. https://doi.org/10.2139/ssrn.3076117

Mazrui, A. (1986). The Africans. London: BBC Publications.

Mills, G. (2010). Why Is Africa Poor? Development policy briefing paper, 6. Available at https://www.cato.org/sites/cato.org/files/pubs/pdf/dbp6.pdf.

\section{Copyrights}

Copyright for this article is retained by the author(s), with first publication rights granted to the journal.

This is an open-access article distributed under the terms and conditions of the Creative Commons Attribution license which permits unrestricted use, distribution, and reproduction in any medium, provided the original work is properly cited. 